\title{
The Baltic Churches and the Challenges of the Post-Communist World
}

Ketola, Mikko

2009

Ketola , M 2009 , ' The Baltic Churches and the Challenges of the Post-Communist World ', pÿlnternational Journal for the Study of the Christian Church , vol. 2009 , no. 3 , pp. 225239 . https://doi.org/10.1080

http://hdl.handle.net/10138/307051

https://doi.org/10.1080/14742250903161888

publishedVersion

Downloaded from Helda, University of Helsinki institutional repository.

This is an electronic reprint of the original article.

This reprint may differ from the original in pagination and typographic detail.

Please cite the original version. 


\section{The Baltic Churches and the Challenges of the Post-Communist World}

\section{Mikko Ketola}

To cite this article: Mikko Ketola (2009) The Baltic Churches and the Challenges of the PostCommunist World, International Journal for the Study of the Christian Church, 9:3, 225-239, DOI: 10.1080/14742250903161888

To link to this article: https://doi.org/10.1080/14742250903161888

册 Published online: 09 Sep 2009.

Submit your article to this journal $\pi$

Џll Article views: 197

Q View related articles ¿ 


\title{
The Baltic Churches and the Challenges of the Post-Communist World
}

\author{
Mikko Ketola
}

\begin{abstract}
This article analyses and describes the recent history of the Baltic churches, their theological reorientation and the challenges they have encountered in the postCommunist Baltic society. The focus is on the Estonian, Latvian and Lithuanian Lutheran churches whereas the Catholic and Orthodox churches receive less attention. It is first demonstrated that much has changed since the Second World War regarding the churches' membership numbers and their societal position. The article then pays attention to two phenomena that have caused much discussion not only within the churches but also among foreign observers: the fear that the Lutheran Church will surrender to the Catholic Church, and the quite opposite anxiety that the Lutheran Church-Missouri Synod will grow too influential within Baltic Lutheranism. Finally, the author examines the way the Baltic churches have been involved in politics during the last two decades.
\end{abstract}

Keywords: Lutheranism in the Baltic countries; religion in the Baltic countries; Lutheran Church-Missouri Synod; Estonia; Latvia; Lithuania; religion and politics; theological conservatism; homosexualism and the Church

In the following, I shall concentrate on post-1989/1991 developments within the Estonian, Latvian and Lithuanian Lutheran churches. Consequently, this article will be less illuminating on the Catholic and Orthodox churches and other, smaller Christian churches in the three Baltic countries. Thus I have had to leave out, for instance, Pope John Paul II's pastoral visitation to the Baltic states in 1993, the first to former Soviet republics. Another issue that would easily merit an article of its own is the rift between the two Orthodox churches in Estonia, the one under the Moscow Patriarchate and the other under the Ecumenical Patriarchate of Constantinople, which opened in the first half of the 1990s and culminated in a temporary suspension of eucharistic communion between the two patriarchates. Still another issue, which would be of great interest, is the problematic process of Vergangenheitsbewältigung or the struggle to come to terms with the past, be it in the area of general politics or within the churches. In order to keep this article within reasonable bounds, however, I shall only point to another article in which I have dealt with that issue. ${ }^{1}$

All this does not mean that I would consider Lutheranism alone the most significant form of Christianity in today's Baltic countries. However, when writing

${ }^{1}$ Cf. Ketola, 'The Baltic Churches'. 
about such a multifaceted phenomenon as contemporary Baltic Christianity, one must choose between treating all actors equally but at the same time superficially and raising some particularly burning issues that one can look at more closely. Viewing all the Baltic churches together naturally carries the danger that the picture becomes too generalised and unified. I have tried to avoid that. It also goes without saying but I shall point it out anyway - that it is difficult, if not impossible, to offer definite analyses and explanations about events and developments belonging to the neueste Zeitgeschichte. For this reason, I would like to characterise most of my analyses as hypotheses demanding further and deeper research. ${ }^{2}$

\section{The changing religious demographics of the Baltic states}

Before the Second World War, one could confidently label the Baltic countries according to religion. Estonia was overwhelmingly Lutheran $(78 \%)$, Latvia was clearly Lutheran (55\%) and Lithuania almost completely Catholic. Labelling is much more difficult today. The changes from the 1930s to the start of the twenty-first century have been comprehensive. For instance, whereas one could call the Lutheran churches of Estonia and Latvia national or people's churches in the 1930s, today they must be called minority or mission churches in a highly secularised society. In Estonia, the Lutheran Church today has only about 39,000 paying or registered members ( $4 \%$ of the population), and in Latvia the absolute number is only a little higher: around 41,000 (around 2\%). In Lithuania, the ethnic make-up of the Lutheran Church changed markedly at the end of the Second World War when the Potsdam Conference of 1945 attributed the former German Memel Region with its many Lutheran parishes to the Lithuanian Soviet Socialist Republic. Today, there are only around 21,000 active members in the Evangelical Lutheran Church of Lithuania.

However, the actual membership numbers the churches themselves give are usually much higher, in Estonia 180,000 and in Latvia 400,000. This means about $13 \%$ and $20 \%$ of the population, respectively. The discrepancy between these two sets of numbers is explained partly by the fact that the churches count as their members all baptised and confirmed people, even if they no longer are active members; furthermore, it is usual that in families only one family member pays the Church membership fee. According to a 2007 poll by the Ministry of Justice, $80 \%$ of Lithuanians were Roman Catholics. ${ }^{3}$

A different matter altogether are various opinion polls which produce data about how many people consider themselves Lutheran, Catholic, etc. In Estonia and Latvia the percentage of people who consider themselves Lutheran is usually in the range $50-60 \%$. Many of these people could probably be called cultural Lutherans who, however, often have a very poor knowledge of the basic tenets and language of Lutheranism. $^{4}$

\footnotetext{
${ }^{2} \mathrm{~A}$ fine collection of analyses on post-1989 developments in the Central and Eastern European churches is Katharina Kunter and Jens Holger Schjørring, Die Kirchen und das Erbe des Kommunismus.

${ }^{3}$ Figures are according to the International Religious Freedom Report 2008 by the US Department of State. http://www.state.gov/g/drl/rls/irf/2008 (accessed 29 May 2009).

${ }^{4}$ So, e.g., the late Estonian Lutheran Archbishop Jaan Kiivit. Cf. Kiivit, 'Uskonnonvapaustilanne Virossa', 550.
} 
When we compare these latest numbers with those of the 1930s, we can see how drastically the religious map has changed. Furthermore, when we consider the fact that the percentage of the Orthodox Estonians is a little under $13 \%$ and increasing steadily, whereas the number of the Lutherans is slowly decreasing, it looks like the Orthodox Church will soon be Estonia's largest denomination. The Estonian sociologist Jaanus Plaat has pointed out three reasons for the fact that by 2000 the number of those who regard themselves as Orthodox has almost reached that of the Lutherans. In the first place, this is due to the great number of Orthodox non-Estonians (mostly Russians). This is compounded by the increasing influence of the Orthodox Church subordinated to the Moscow Patriarchate among the Russianspeaking population in the 1990s. And third, the Estonian Evangelical Lutheran Church has steadily been losing members. ${ }^{5}$

In Latvia, the Catholic Church boasts nearly half a million baptised members, of which around half are said to be active members of the Church. To many observers it seems certain that Latvia could soon be called a Catholic country. ${ }^{6}$ Even the Orthodox Church has nearly as many members as the Lutheran Church. Still, one cannot trust these figures completely. In any case, it is certain that there is no return to the dominance of Lutheranism in Estonia and Latvia. Furthermore, in Estonia, the membership of the Lutheran Church has been on the decline since the beginning of the 1990s. This has been most evident in the countryside, where the Estonian state's severe agricultural policy has led to emptying villages and thus the liquidation of many parishes as well. In most countryside parishes, membership numbers rarely exceed 400. Declining numbers evidently lead to a marginalisation of the church in civil society and in democratic political life. The current economic crisis has forced an increasing number of Estonian Lutheran pastors working in small parishes to take a second job in order make a decent living. Their average salary is usually around 400 euros a month. ${ }^{7}$

In Lithuania, the Catholic Church still comprises formally around $80 \%$ of the people, but many experts doubt whether Lithuania ought to be called a Catholic country any longer. It has been estimated that as little as $15 \%$ of Lithuanians are active, churchgoing Catholics. Although the Catholic Church united Lithuanians across a wide front in her ideological resistance to Soviet totalitarianism, it seems that the Church's mass appeal was more political than spiritual. It appears that the Catholic Church in Lithuania has had to concede ground to advancing secularisation almost to the same degree as have other churches in post-Communist societies. In general, however, the Catholic Church seems to have weathered the anti-religious ideology and policies of Communism better than the Protestant churches. If we take Latvia, it seems that Catholic lay people especially remained loyal to their Church to a higher degree than their counterparts in the Lutheran Church. Even in Estonia, the minuscule Catholic Church appears to be growing comparatively faster than either the Lutheran or the Orthodox churches. Then again, this is the situation in Finland as well, where the growth of the relatively small Catholic Church is fuelled primarily by immigration.

\footnotetext{
${ }^{5}$ Plaat, 'Eesti', 588; Plaat, 'Christian', 102.

${ }^{6}$ Benz, 'Wird Lettland katholisch?', 25-8.

${ }^{7}$ Jussi Rytkönen, 'Viron papisto turvautuu sivutöihin' [The Estonian clergy has to take recourse to second jobs]. Kotimaa.fi. http://www.kotimaa.fi/index.php?option=com content\&task $=$ view $\& i d=8709 \&$ Itemid $=38$ (accessed 28 May 2009).
} 
None of the Baltic churches are state churches, although in Latvia and Lithuania the state recognises and favours certain traditional or historic religious communities. In Latvia the government distinguishes between 'traditional' (Lutheran, Roman Catholic, Orthodox, Old Believers, Baptists and Jewish) and 'new' religions. ${ }^{8}$ In Lithuania, the constitution specifies as historic the following nine religious communities: Latin Rite Catholics, Greek Rite Catholics, Evangelical Lutherans, Evangelical Reformed Church, Orthodox Christians (Moscow Patriarchate), Old Believers, Jews, Sunni Muslims and Karaites. ${ }^{9}$ In Estonia, all churches are equal before the law.

According to several recent studies, Estonia has become one of the most secularised countries in the world. Only a little more than $30 \%$ of Estonians confess to a religious faith. In the media, the long-advanced secularisation is usually regarded as a positive development. The Estonian Lutheran theologian Urmas Petti has described the attitude thus: 'Educated and rational people as we all like to regard ourselves don't believe in stories about fairies, Father Christmas or God. In the second place, we don't need the guardianship of any institution, like the church'. In fact, one can often observe Estonians expressing pride in their country's high degree of secularisation. ${ }^{10}$ This was aptly reflected in a recent Estonian advertising competition, where a youth team called Funda won the first prize in their class with a tourism poster using only a map of Estonia and a couple of lines from John Lennon's song 'Imagine': 'Nothing to kill or die for / And no religion too'. ${ }^{11}$

\section{The spectre of Catholicism?}

The diminishing stature and influence of the Lutheran churches in Latvia and Estonia has recently caused reactions in connection with which it is perhaps appropriate to paraphrase Karl Marx: A spectre is haunting the Baltic Lutherans the spectre of Catholicism. Fear of Catholicism is not a new phenomenon in Estonia and Latvia. It was especially strong in the 1930s when the Vatican was actively and conspicuously looking for closer contact with the Estonian and Latvian Orthodox in order to find out whether the Orthodox churches were interested in starting union negotiations with the Catholic Church. At the time this caused anxiety especially among the strongly confessional Baltic German Lutherans. ${ }^{12}$

On 12 April 2009, the Latvian state broadcasting company released news that the Latvian Lutheran Church was planning to negotiate a merger with the Catholic Church in Latvia. However, it soon turned out that the news was highly premature, or, in the words of the Lutheran Archbishop Janis Vanags, 'grotesque and in an

\footnotetext{
${ }^{8}$ Latvia. International Religious Freedom Report 2008. US Department of State. http:// www.state.gov/g/drl/rls/irf/2008/108454.htm (accessed 29 May 2009).

${ }^{9}$ Lithuania. International Religious Freedom Report 2008. US Department of State. http:// www.state.gov/g/drl/rls/irf/2008/108456.htm (accessed 29 May 2009).

${ }^{10}$ Petti, 'Estnische', 122. Also Altnurme, 'Vergangenheitsbewältigung und Neuanfang?', 138.

${ }^{11}$ 'Noored tutvustavad Eestit paganliku maana' [Youths present Estonia as a heathen country], Postimees, 12 April 2008, http://www.postimees.ee/160408/esileht/meedia/323393.php (accessed 28 May 2009).

${ }^{12}$ I have recently started a research project on the Vatican's intentions regarding the Baltic countries in the 1930s based on the newly released documents in the Vatican Secret Archives. Cf. for instance P. Rittmeister, SJ, 'Die Lage der Orthodoxie in Estland' (written probably in Summer 1934), Archivio Segreto Vaticano, Affari Ecclesiastici Straordinari, Paesi Baltici, 4. periodo, pos. 93, fasc. 99.
} 
absurd way taken out of context'. Vanags had in fact met in November 2008 with Cardinal Walter Kasper, President of the Pontifical Council for Promoting Christian Unity, at the Vatican and soon after that with the Latvian Cardinal Janis Pujats to discuss relations between the two churches, but these two meetings were reportedly only meant to increase mutual knowledge and provide an opportunity for comparing notes. Vanags said that the two churches had been in close contact for a long time but there were still many grave points of theological disagreement. ${ }^{13}$

On the one hand, it was not surprising that an outside observer would assume a merger between the churches was drawing near. They had been co-operating closely and publicly on many social questions, and Archbishop Vanags had repeatedly stressed that the smaller Lutheran Church had to take into consideration the conservative opinions and position of its bigger sister churches, both Catholic and Orthodox, when speaking out on issues such as the ordination of women or same-sex relationships. Vanags had stopped ordaining women after he became Archbishop in 1993. Indeed, two Latvian researchers opined already in 1999 that attitudes towards many things in the Latvian Lutheran Church 'can be described as Catholic' and the Lutheran Church had never been closer to the Catholic Church. ${ }^{14}$

However, one has to remember that the Latvian Lutheran Church is still far even from internal unity. Spiritual and structural unification of the Latvian Evangelical Lutheran Church and the Latvian Evangelical Lutheran Church Abroad is not in sight. There are so many differing theological opinions within the Church that Archbishop Vanags has described attending a pastors' conference as being 'at an ecumenical assembly rather than at a meeting of our Church'. ${ }^{15}$ It would thus be a very challenging task to reach any sort of doctrinal agreement between two such disparate parties as the Catholic Church and the Latvian Evangelical Lutheran Church.

Latvia is not the only Baltic country where the spectre of Catholicism has been used as a weapon by those who are obviously concerned that the Catholic Church is gaining too much ground at the expense of the Lutheran Church. In Estonia, these anxieties came to the fore in connection with the process of approving a new Service Book for the Lutheran Church. It had been in preparation since the early 1990s. The creators of the new Service Book aimed to renew the liturgy following in the first place the example of similar reforms in the Finnish, Scandinavian and other Lutheran churches. This included better involvement of the laity in the service, more Bible reading, new church music and so on.

As the time for voting on the new Service Book approached, it became clear that many pastors and church musicians in the Estonian Lutheran Church were strongly opposed to the renewal of the liturgy. They demanded that those who could not accept the new liturgical order be allowed to continue using the old Service Book. In their view, the new order was foreign to traditional Estonian Lutheran sensibilities and far too Catholic. They were especially suspicious of the use of the word 'Mass' and worried that the sermon would no longer be the most important part of the service. The opponents of the new Service Book claimed that there was an influential

\footnotetext{
'Läti peapiiskop: luteri kirik ei liitu katoliku kirikuga' [The Latvian Archbishop: The Lutheran Church won't merge with the Catholic Church], Eesti Päevaleht, 13 April 2009, http://www.epl.ee/artikkel/465240 (accessed 29 May 2009).

${ }^{14}$ Gills \& Krumina-Konkova, 'The Latvian', 204.

${ }^{15}$ Zviedre, 'Life Stories', 199-200.
} 
'interest group' within the Church which in reality regarded the Catholic Church as the only true church and wanted to lead the Estonian Lutheran Church surreptitiously into its arms. They called the members of this group 'cryptocatholics'. ${ }^{16}$ This was an obvious reference to High Church circles within the Estonian Lutheran Church. The struggle between Low Church and High Church ideas in the Church had its roots at the time when Estonia became independent and the Lutheran Church elected the first Estonian bishop, Jakob Kukk. ${ }^{17}$

In the Lutheran Church Theologians' Conference in January 2008 the proposal for the new Service Book won a simple majority but not the two-thirds majority which was required for approval. Thus it could not be sent forward to the Church Diet. Discussion became so heated that warnings about an impending church division were aired. Archbishop Andres Põder was even seriously asked in an interview whether the Estonian Lutheran Church could turn into a Catholic Church, to which he curtly replied, 'no'. ${ }^{18}$

However, although it seems obvious that the anxiety of those who fear the cryptocatholics' devious plans is misguided, even paranoid, there are signs that there will in the future be closer ecumenical contacts between the Catholic Church and the Baltic Lutheran churches. A joint theological conference between the churches is said to be in the planning stages. ${ }^{19}$

\section{The growing influence of the Lutheran Church-Missouri Synod}

Perhaps the most weighty factor speaking against an impending merger of the churches is the fact that the Lutheran churches of Latvia and Lithuania have since the late 1990s found agreement on many issues with the conservative American Lutheran Church-Missouri Synod (LCMS). This co-operation has also entailed material support for these two Baltic churches. A church intending to seek unity with the Catholic Church would probably not first create close ties with the strongly confessional, even anti-ecumenical, LCMS.

There are several reasons behind the success of the LCMS's recent advances in Latvia and Lithuania. One important factor can be described as a growing 'confessional awareness'. This means in short a conviction that almost all Western Lutherans have strayed from the orthodox understanding of Lutheranism's central tenets and that the Lutheran churches in the Baltic countries are almost alone fighting back against a corrupting spirit of materialism and 'secular humanism'. 'Disillusioned' Lithuanian Lutherans returning from international conferences and other trips abroad observed that 'a secular agenda had been raised to a level equal to the Gospel of Jesus Christ' and that 'traditional spirituality had been replaced by environmental and social justice concerns'. ${ }^{20}$ 'Confessional awareness' is sometimes combined with nostalgia for certain aspects of the Soviet era, when it was easier for a Christian to know who the enemy was. It also meant that it was easier for a Christian

\footnotetext{
${ }^{16}$ Jaan Lahe, 'Millist kirik me tahame?' [What kind of Church do we want?], Eesti Kirik, 6 June 2007, http://www.eestikirik.ee/node/3086 (accessed 28 May 2009).

${ }^{17}$ Cf. Ketola, The Nationality Question, 80-1.

${ }^{18}$ 'Tegu on missakorra tänapäevastamisega' [It is about updating the order of the Mass], Pärnu Postimees, 2 August 2008, http://www.parnupostimees.ee/030808/artiklid/100879580.0php (accessed 28 May 2009).

${ }^{19}$ Dr Pastor Darius Petkunas's communication to the author, 10 May 2009.

${ }^{20}$ Petkunas, Resurgence, 31 .
} 
to form his own identity. In an interview, Archbishop Vanags put it in a way which probably holds true for many of his contemporaries: 'Persecution acted as a cleansing force on the Church. All that was false, redundant, ballast, fell away. Those who continued practising faith were those for whom it was a question of life or death - the most important issue of all'. ${ }^{21}$

Baltic church leaders have at times been very sensitive to both real and imagined attempts at pressure by Western church bodies, for instance concerning female ordination. This sort of Western ecclesiastical besserwisserism, as it has been called, and the offence caused by it, may also be a factor contributing to a turning towards more conservative theological thinking. ${ }^{22}$ In this respect, the Baltic Lutheran churches have a sort of love-hate relationship with the Nordelbische EvangelischLutherische Kirche and the Church of Sweden. They are important co-operation partners and without their economic help the Baltic churches would be in trouble. On the other hand, they are perhaps the two most liberal Lutheran churches in the world and thus a source of much theological grief for the Baltic churches they are assisting.

Co-operation between the Baltic Lutherans and the LCMS started sometime in the mid-1990s. In Lithuania, it was preceded by a feeling that the Church was being pressured from the outside, especially by their close German partners and supporters, the Nordelbische Evangelisch-Lutherische Kirche and the Lippische Landeskirche, to adopt liberal theological views and start ordaining women to the priesthood. However, 'a new scientific view of the Bible' did not gain much traction among the Lutheran clergy. For many of them, scholarly study of the Bible was just another name for the method favoured by the Soviet atheistic propagandists who had often sought support for their claims from 'German higher critics' such as Rudolf Bultmann whom they had called 'the Copernicus of Biblical exegesis'. ${ }^{23}$

The Lithuanian Lutheran Bishop Jonas Kalvanas Sr had ordained a woman to the service of the Lithuanian Evangelical Lutheran Church in Exile in 1990, at a time when 'few church officials felt any need to enter the debates against the ordination of women'. ${ }^{24}$ When Bishop Kalvanas died in early 1995 there were strong expectations that the Church would finally start liberalising. Prominent Western observers such as Gerd Stricker of Glaube in der 2. Welt weighed in and predicted a possible rift within the Church between those who wanted to see Bishop Kalvanas's son as his successor and those who wanted to have more democracy and women pastors in the Church. ${ }^{25}$

Soon after Bishop Kalvanas Sr died, a member of the Vilnius parish who had just completed her studies at Wycliffe Hall, a Church of England theological college in Oxford, requested that the Lutheran consistory ordain her as a pastor in the Lithuanian Lutheran Church. The request was first tabled and then denied along with another similar application. Henning Kramer, the vice-president of the Nordelbische Kirche tried personally to persuade the Lithuanians to follow the course of their partner churches in Germany and Scandinavia and approve the

\footnotetext{
${ }^{21}$ Zviedre, 'Life Stories', 198.

${ }^{22}$ Stricker, 'Umstrittene Frauenordination', 20-3.

${ }^{23}$ Petkunas, Resurgence, 23-5.

${ }^{24}$ Ibid., 23.

${ }^{25}$ Stricker, 'Bischofsnachfolge', 6.
} 
ordination of women. He pointed out that a negative decision could be 'construed as a highly prejudicial and discriminatory action'. ${ }^{26}$

At the July 1995 synod of the Church, Bishop Kalvanas Jr was elected bishop. The synod also discussed heatedly the subject of women and the ministry. A letter from the Nordelbische Kirche, insisting that the ministry be opened to women, was read aloud. Otherwise, it suggested, the German partners would be free to draw their own conclusions. The obvious threat of losing the Germans' financial support caused palpable anxiety among the participants. Finally, the synod decided not to vote on the issue until the question had been investigated by a special theological commission. The commission was established, but its task remains unfinished. No new women pastors have been ordained to the priesthood in Lithuania since the 1990s.

'Confessional awareness' surely played the key role in the rejection of female priesthood in Lithuania, but there may have been one further influential factor. There was the - perhaps unconscious - influence of the 'mighty Catholic Church' on the thinking of the small band of Lutherans, as the Lithuanian Lutheran Bishop Jonas Kalvanas Jr allegedly told a German writer. ${ }^{27}$

The Lutheran World Federation and other Western observers continued to put pressure on both the Latvian and Lithuanian Lutheran churches to approve the ordination of women but with no results. According to the Lithuanians themselves, a further factor convincing them of the corrupt nature of Western Lutheran churches was the Joint Declaration on the Doctrine of Justification, agreed to by representatives of the Catholic Church and the Lutheran World Federation in 1999. The Lithuanian Lutherans decided that they could not support the declaration as 'an accurate reflection of Lutheran and biblical theology'. ${ }^{28}$

As the turn of the millennium approached, co-operation between the Lithuanian Lutherans and the LCMS grew ever tighter. The two churches organised joint conferences in Lithuania in 1998 (Taurage) and 2000 (Klaipeda). For the next synod, which was held in 2000, the Lutheran consistory proposed that the Church seek intercommunion with the LCMS. The synod eventually approved the proposal but only after heated discussion. Glaube in der 2. Welt reported that the delegates felt themselves under pressure to approve the proposal because there were five representatives of the LCMS among the participants. Vice-president Henning Kramer from the Nordelbische Kirche stated that his Church would have to withdraw their financial support from the Lithuanians because they disapproved of the LCMS's anti-ecumenical line. The director of the Theological Center in Memel, H. Arnasius, warned that a positive decision would mean a spiritual separation from the rest of Europe. The reasons cited for the decision to seek 'a closer and deeper relationship' with the LCMS were the Church's 'clear and orthodox position regarding the authority of the Scripture, confessional subscription, and sexual morality'. 29

The next year, the synod of the Latvian Lutheran Church arrived at a similar decision. Again there was fierce opposition, e.g., from the dean of the Theological Faculty in Riga, who suspected that only a few of the 200 people present at the synod

\footnotetext{
${ }^{26}$ Petkunas, Resurgence, 26.

${ }^{27}$ Lipsius, 'Die Erneuerung', 103.

${ }^{28}$ Petkunas, Resurgence, $32-3$.

${ }^{29}$ Ibid., 34-5.
} 
knew enough of the theology and character of the LCMS to arrive at an informed decision. He considered it unwise to narrow the Latvian Lutheran Church's foreign co-operation to just one conservative church. Other voices warned that the Latvian Church would isolate itself, lose foreign financial support and endanger its existing international relationships. Archbishop Vanags was annoyed with the tactics of the opposition, blaming it for discrediting the whole Church in front of the Latvian public. 'Something like this would not have happened in the Catholic Church,' Vanags reportedly complained. ${ }^{30}$

In 2001, the delegate convention of the Lutheran Church-Missouri Synod decided to establish fellowship with both the Latvian and Lithuanian Lutheran churches. The Lithuanian Lutheran Church continued on the same track when it decided to move toward closer relations with the conservative Independent Evangelical Lutheran Church in Germany in 2005. ${ }^{31}$ Western criticism of the Latvian and Lithuanian choice of theological orientation has elicited countercriticism regarding the failure of Western observers to understand the mentality within these Baltic churches. In this view, the larger European churches have 'failed to appreciate the rising tide of confessional awareness in the Lithuanian and other Eastern Lutheran Churches'. Furthermore, Western Lutherans are blind to the fact that the decision to seek closer contact with the LCMS was 'a response to the modern liberal orientation in theology and ecclesiology in the Western European Churches'. ${ }^{32}$ Many church leaders in Eastern Europe also think they see a connection between rampant consumerism and societal ills considered as Western imports and the moral bankruptcy of Western theology. ${ }^{33}$

So far, the Estonian Lutheran Church has not sought closer ties with the LCMS. Still, it is obvious that all the Baltic Lutheran churches are of one mind when it comes to certain matters, for example, attitude toward homosexual relations and their sinfulness. In 2006, Baltic Lutheran church leaders sent a joint letter of protest to the Church of Sweden, lamenting the decision of its General Synod on 27 October 2005 to bless homosexual partnerships, as weakening unity and co-operation among the churches. In the letter, the leaders of the Baltic Lutheran churches declared that 'the blessing of homosexual unions would not be tolerated in their own churches, and that they cannot continue in fellowship with priests of sister churches who practice or support blessing of same-sex couples'. ${ }^{34}$ Thus, although there are often significant differences in the intensity and character of the conservatives' conservatism in the different Baltic countries, with respect to some issues they are easily able to build a unified front.

\section{The churches, politics and Christian values}

It is well known that the churches in each Baltic country had a significant role in the restoration of national sovereignty. However, there were interesting differences. In Lithuania and Latvia, the churches acted as a springboard or a home for forces

\footnotetext{
${ }^{30}$ Stricker, 'Lutheraner und Missouri', 5.

${ }^{31}$ Petkunas, Resurgence, 35, 47.

${ }^{32}$ Ibid., 37-8.

${ }^{33}$ Walters, 'The Revolutions in Eastern Europe', 360.

${ }^{34}$ Lithuanian Evangelical Lutheran Church, 'Concerned about Unity', http://www. liuteronai.lt/titulinis/straipsniai/2006/santuoka/santuoka_ang.htm (accessed 29 May 2009).
} 
striving for independence. There, the resistance to a large extent originated or at least was channelled through the churches. In Lithuania, as in Poland, the Catholic Church was a strong national force. It had a Soviet Union-wide reputation as a bastion of civil resistance against Soviet ideology. It always had strong connections to human rights activists within the Soviet Union, for instance to Andrei Sakharov and Sergei Kovaljov. ${ }^{35}$ In the Latvian and Estonian churches, human rights issues never played such a significant role. Even today, there is a debate within the Estonian Lutheran Church, for instance, about whether human rights issues should be a matter for the Church at all.

Although in Latvia the leadership of the Lutheran Church was very loyal to the Soviet state, during glasnost and perestroika a group of young reform-minded pastors organised the Rebirth and Renewal movement to defend the rights of Christians. The movement was active in extending a Christian influence into Soviet Latvian society. Latvia became the first Soviet republic in which the Christian message was broadcast on public radio and TV and in which religious instruction was provided in schools. Some of the movement's members helped to found the Popular Front of Latvia, a party that played an active role in regaining Latvian independence in 1991. ${ }^{36}$

In Latvia and Lithuania there were also forces within the churches which were not so eager to see the status quo ended, but they were soon overwhelmed and pushed aside. In Latvia, the whole Lutheran consistory, including the archbishop, was voted out of office in 1989. It was accused of having cared too much for the welfare of the Soviet state and too little for Latvian Christians. Similarly, in Estonia, the whole Lutheran consistory was also replaced in 1990, but Archbishop Kuno Pajula was allowed to remain in office. Everyone knew that he had been a loyal servant of the Soviet state, but as he had obviously not harmed the Church and had shown a positive attitude towards reforms, no one wanted to humiliate him. The differences between the Latvian and Estonian modes of action have also been explained in terms of different national characteristics and mentality. ${ }^{37}$

In Estonia, the Lutheran Church had not been in the same manner a cornerstone of the opposition movement. The Church had been closely controlled by the Soviet security organs and had never been an essential component of Estonian national identity. This image and the fact that the Church had never spoken out against the strong Russification policies of the state had alienated most ordinary people. Nevertheless, when the campaign for the restoration of Estonian independence started, the Lutheran Church and individual pastors became strongly involved, especially in the activities of the Estonian Heritage Society. The Society, by restoring churches and monuments destroyed by the Communist regime, worked to revive Estonian national history and cultural traditions as well as combat Soviet propaganda. A Lutheran pastor blessing a restored national monument in one Estonian town or another became a familiar sight in the late $1980 \mathrm{~s}^{38}$

\footnotetext{
${ }^{35}$ Fischer, 'Litauen', 21-2; Fischer, 'Katholische Kirche', 26-8.

${ }^{36}$ Friedrich, 'Lettlands Kirche', 19-24; Rozitis, 'Wiedergeburt und Erneuerung', 21-4; Gills and Krumina-Konkova, 'The Latvian', 201-9; Cf. also Elmar E. Rozitis's reports on the Latvian Evangelical Church in Kirche im Osten 29-37 (1986-94).

${ }^{37}$ Stricker, 'Estlands Lutheraner', 17-21.

${ }^{38}$ Pastor Burchard Lieberg chronicles the years 1986-1992 very informatively in his reports on Estonian church life in Kirche im Osten 29-37 (1986-94). Altnurme, 'Die Phase des Zusammenbruchs', 64-70.
} 
Christian democratic parties have not been very successful in any of the Baltic states. Individual pastors have been active in party politics in Latvia and Estonia, and many of them have been elected to parliament in both countries from the ranks of different parties. In Lithuania, however, Catholic priests have evidently not been members of parliament, although many of them were active in Sajudis, the political organisation which led the struggle for Lithuanian independence in the late 1980s and early 1990s.

In both Latvia and Lithuania, church leaders have criticised politicians for failing to take satisfactory measures against a wide range of political and social problems that cause concern for the churches. Corruption in state and government circles, child abuse, pornography, alcoholism and drug abuse are furthermore commonly seen as Western imports or caused by the reckless capitalism allowed by politicians. On some occasions the bitter disillusionment with the post-Communist reality has led to outright nostalgia for Soviet times. For instance, the leaders of both the Lutheran and Catholic churches in Latvia are known to have expressed views that the immorality they were witnessing would not have been allowed under the Soviet regime. The Latvian Cardinal Janis Pujats has recently accused the post-Communist Latvian governments of marginalising religion. ${ }^{39}$ In Lithuania, church leaders have complained that there are still too many members of the former Soviet nomenklatura in influential positions, acting systematically against the Church. ${ }^{40}$

This sort of disillusionment was illustrated vividly by the boycott staged by Latvia's Lutheran, Roman Catholic, Orthodox and Baptist Church leaders in connection with the main service to mark Independence Day on 18 November 2000. The service took place in Riga's Lutheran Cathedral and was attended by the country's president and prime minister. Although present, church leaders refused to take an active part in the service, leaving the sermon and the prayers to be delivered by ordinary priests and pastors. The Lutheran Archbishop Vanags said the protest had been staged to focus attention on disappointed public expectations and accused the country's politicians of betraying the 'hopes and emotions' born in 1991, when Latvia achieved independence. However, he denied that he was engaged in a conflict with the country's president. ${ }^{41}$

At the beginning of the new millennium, American culture wars were to some extent imported to Latvia. The term culture war is not easy to define, but in the United States it has involved politically conservative religious circles, the Evangelicals being the largest single grouping, who consider public morality a defining issue in party politics. Family values is a slogan much used by the culture war warriors. In Latvia, this sort of ideological battle was initiated in 2002 by the Latvia First Party. The Party was founded by Eriks Jekabsons, a devout Christian who fled the Soviet Union in 1988 due to alleged KGB persecution and spent the following 13 years in the United States, where he received a master's degree in theology and served for five years as a Lutheran pastor in Chicago. Upon his return to Latvia in 2001 he said in an interview: 'Many of our parliamentary deputies are not religious, but in America people understand that politics without morality is

\footnotetext{
39،'Stimmungsbild der Katholiken', Glaube in der 2. Welt 30, no. 10 (2002): 5.

${ }^{40}$ 'Stellungnahme katholischer Bischöfe', Glaube in der 2. Welt 20, no. 11 (1992): 4.

${ }^{41}$ 'Latvia's Lutheran church leader accuses politicians of betrayal', LWI News in brief NOV./ DEC. edition. http://www.wfn.org/2000/12/msg00207.html (accessed 29 May 2009).
} 
maimed, and morality without religion is impossible. Latvia's politicians and society don't realize that'. 42

The Latvia First Party won 10 seats in the 101-member parliament in the 2002 elections on an American-style 'Christian family values' platform. Whereas, in general, Latvia's political parties are rigidly separated on ethnic lines, the Latvia First Party explicitly endorsed multiculturalism and ethnic integration during the 2002 campaign, seeking to win support among Russian-speaking voters. The Party has also been explicitly homophobic since its founding congress, and one of its main contributions to Latvia's political culture has been the mainstreaming of homophobia. The Party's aggressive use of anti-gay rhetoric in its 2002 campaign suggests that it views homophobia as a useful replacement for anti-Russian nationalism and an idea that could unite Latvians and Russians. ${ }^{43}$

Homophobia is strong in Latvian church circles as well. The Lutheran Archbishop Janis Vanags banned practising gays from receiving Holy Communion in 1994. Vanags and the Roman Catholic Archbishop of Riga Janis Pujats contributed chapters to a book published in 2002 by the radical nationalist Aivars Garda, entitled Homosexuality: Humanity's Shame and Ruin. The roots of this strong homophobia can be found partly in the Soviet moral code and education. In the Soviet Union, homosexuality was a crime.

Since its election success, the Latvia First Party has spoken out against abortion and campaigned for references to Christian heritage to be included in the EU constitution treaty. It also secured a highly controversial budgetary allocation for church renovations under the rubric of promoting 'sacred' tourism, which critics have denounced as a transparent effort to win endorsements from the pulpit. The party is nicknamed 'the Preachers' Party', because clergy are prominent in its membership. The party cultivates connections with all of Latvia's mainstream denominations, but it has reportedly provoked widespread scepticism through its close ties with evangelical churches. ${ }^{44}$

In the summer of 2005, the Latvia First Party was one of the organisers in a demonstration against the country's first Gay Pride parade. The intensity of homophobia in Latvia is well illustrated by the fact that, for the first time in a European Union member-state, politicians at the national level - including prime minister - denounced the march.

The question of the prominence and practical realisation of Christian values in politics is a tricky one. In Estonia, the Lutheran Church organised a conference in November 2005 entitled 'Christian Values in Estonian Politics'. The president, the prime minister and all the political parties were represented, and all of them had their own views about what sort of influence Christian values should have in political decision-making. Most of the politicians agreed that contemporary ethical norms have their basis in Christian ethics and that Christian values are needed in Estonian politics. Family values and their importance were especially underlined heavily in several contributions. The Estonian prime minister expressed his hope that religious

\footnotetext{
${ }^{42}$ Katrina Z.S. Schwartz, 'Gay rights: United in Hostility'. Central and Eastern European Online Library, http://www.ceeol.com/aspx/getdocument.aspx?logid=5\&id=A03F7CF2-5560-4AECBFF4-28874C746F48 (accessed 29 May 2009).

${ }^{43}$ Ibid.

${ }^{44}$ Ibid.
} 
education would soon be a compulsory subject in school. ${ }^{45}$ Religious education is one of the greatest causes of controversy between church and state in each of the Baltic countries.

It seems that in Estonia many leading politicians have a positive personal attitude towards the Church and are willing to pay homage to Christian values. It is of course another matter whether this goodwill translates into concrete political action. Estonian politicians must take into account the fact that many Estonians take a sceptical view of any kind of organised religion. They are in fact proud of how secularised Estonia is. As the Estonian opposition leader Edgar Savisaar says about his relation to religion: 'My relation to religion is typically Estonian, not very churchy. I admit there must be religion and that Lutheranism was the religion of my ancestors, but I don't consider myself a fiery believer'. ${ }^{46}$ The image of an ordinary church member as a fiery believer - meaning a dangerous and ignorant fanatic - is one of the unfortunate results of Soviet propaganda. In the opinion of Pastor Villu Jurjo, a famous dissident in the Soviet period, the Russian party in Estonia is nowadays the only party where the significance of churches is really understood and valued. ${ }^{47}$

The mainstream churches in all three Baltic states were clearly in favour of EU membership. In Estonia, the leaders of the EELC favoured EU membership, whereas some free churches said it was a matter of individual conscience. The public declaration of EELC in favour of EU three weeks before the referendum of 2003 received a lot of publicity in the media. Archbishop Jaan Kiivit stressed that Christian traditions have always shaped the European mind and Estonia has always belonged to Europe. ${ }^{48}$ In this he echoed the Estonian president Lennart Meri who had regularly stressed this view in his speeches. Fears were also expressed that support from the Church might have a negative effect on the Estonians' vote. Many of the arguments against Estonian membership were of a religious nature, portraying the EU as a conspiracy of anti-Christian groups. These arguments often came from evangelical free church circles. In the referendum, $66 \%$ of Estonians voted in favour of joining the EU. ${ }^{49}$

The Estonian Lutheran Church's clear but simple EU campaign was nevertheless nothing compared to Lithuania where the unrestrained participation of the Catholic hierarchy in a political campaign was considered quite exceptional. Formal and informal Church networks encouraged participation in the referendum and sent clear signals in favour of accession. Churches themselves were one of the most reliable places to find information on EU accession. Special leaflets could be found in every church, and priests handed out flyers after masses. One Lithuanian bishop reportedly joined a rock concert on the eve of the Lithuanian referendum. According

\footnotetext{
${ }^{45}$ Andrus Ansip, 'Kasvame kristlikel juurtel' [We have Christian roots], Konverents Kristlikud väärtused Eesti poliitikas, Eesti Evangeelne Luterlik Kirik, http://www.eelk.ee/ettekanne. php?id=23 (accessed 29 May 2009).

${ }^{46}$ Edgar Savisaar, 'Ajaloo mõte on selles, et teda teha' [The meaning of history is in doing it], Maaleht, 25 May 2000, http://paber.maaleht.ee/LEHT/2000/05/25/leht.html (accessed 29 May 2009).

${ }^{47}$ Villu Jürjo, 'Olla õigel momendil õiges kohas on kui auhind' [To be at the right moment at the right place is like winning a prize], Póhjarannik, 28 May 2006, http://www.pohjarannik.ee/ modules.php? name $=$ News\&file $=$ article $\&$ sid $=2933$ (accessed 29 May 2009).

${ }^{48}$ 'Luterlik kirik palvetab ELiga ühinemise eest' [The Lutheran Church prays for joining the EU], Eesti Päevaleht, 27 August 2003, http://www.epl.ee/artikkel/243728 (accessed 29 May 2009).

${ }^{49}$ Altnurme, 'Vergangenheitsbewältigung und Neuanfang?', 139.
} 
to the head of the central election office in Vilnius, local priests urged their congregations to cast their votes on leaving church on the Sunday when the referendum took place. After the referendum, the chairman of the Lithuanian parliament singled out clergymen in his remarks, thanking them for urging parishioners to cast their ballots. It has been estimated that the intensive involvement of the Catholic Church might have been one of the most important factors in explaining the positive result. ${ }^{50}$ This explanation may, however, be too simple, because the Catholic Church does not have as much popular influence as it has in Poland, for instance. The active campaigning of the church in Lithuania must also be seen in the wider context: From the Vatican came a clear signal as to how Catholics should vote on this issue.

\section{What will the future hold for the Baltic churches?}

In some ways the predicament of the Baltic churches may be a forewarning of what will be in store for the churches in the West if secularisation continues to advance at the present pace unless there is a renaissance of religion and an improvement of the economic circumstances waiting around the corner. Diminishing membership, declining financial resources, dwindling societal influence, increasing moral and theological conservatism on issues like women, abortion and homosexuality characterise especially the situation of the Lutheran churches in the Baltic states. The Catholic and Orthodox churches seem to have fared somewhat better in material and membership respects. Of course, one must take into account the fact that the Baltic churches were badly equipped to meet the modern world after the long Communist imprisonment. The churches in the West have better tools and resources to meet challenges.

There are, however, also opportunities for the Baltic churches. The churches may in the future have a more deeply committed membership, inspiring others to join on the strength of their personal example. The churches may be pushed to pool resources and increase co-operation at all levels, thus leading to a sort of 'practical ecumenism' and a reduction of old theological enmities. Lay people, especially women, may come to have a more prominent and responsible role in church and parish government, although it seems that the ordination of women in the Latvian and Lithuanian Lutheran churches will be in limbo for the foreseeable future. Governments will perhaps acknowledge the churches' importance in advancing tolerance and pluralism, not only moral intolerance.

\section{Notes on contributor}

Mikko Ketola holds a PhD in Theology from the University of Helsinki. His published works have focused on inter-war Estonian church history, post-Communist Baltic churches, contemporary Finnish church history and post-Vatican II Catholicism. He is currently writing a book about the Estonian churches during the Second World War, and is involved in a research project which will focus on the Vatican's attitude toward nationalism in inter-war Europe. He is Chair of the Finnish Society of Church History and Editor of the Society's Yearbook.

\footnotetext{
50،Lithuania Votes - Or Does It?’, British Helsinki Human Rights Group, 13 May 2003. http://www.bhhrg.org (accessed 10 January 2007; can no longer be found); 'Referendum Briefing no 8. The Lithuanian EU accession referendum 10-11 May 2003'. Sussex European Institute, http://www.sussex.ac.uk/sei/documents/epernbreflith.pdf (accessed 29 May 2009).
} 


\section{Bibliography}

Altnurme, Riho. 'Die Phase des Zusammenbruchs der kommunistischen Herrschaft in Estland, Lettland und Litauen'. In Wie die Träumenden. Protestantische Kirchen in der Phase des Zusammenbruchs der kommunistischen Herrschaft im östlichen Europa, ed. Peter Maser and Jens-Holger Schjørring, 64-70. Erlangen: Martin-Luther-Verlag, 2003.

. 'Vergangenheitsbewältigung und Neuanfang? Fallbeispiel: Estnische EvangelischLutherische Kirche (EELK)'. In Die Kirchen und das Erbe des Kommunismus. Die Zeit nach 1989 - Zäsur, Vergangenheitsbewältigung und Neubeginn, ed. Katharina Kunter and Jens Holger Schjørring, 130-42. Erlangen: Martin-Luther-Verlag, 2007.

Benz, Ernst. 'Wird Lettland katholisch?'. Glaube in der 2. Welt 23, no. 1 (1995): 25-8.

Fischer, Hans-Friedrich. 'Katholische Kirche in Litauen'. Glaube in der 2. Welt 28, no. 10 (2000): 26-8.

'Litauen - Land der Kreuze'. Glaube in der 2. Welt 24, no. 6 (1996): 21-2.

Friedrich, Klaus. 'Lettlands Kirche und die Freiheit'. Glaube in der 2. Welt 20, no. 11 (1992): $19-24$.

Gills, Nikandrs, and Krumina-Konkova Solveiga. 'The Latvian Evangelical Lutheran Church on the Threshold of the Year 2000'. Religion, State and Society 27 (1999): 201-10.

Hoppenbrouwers, Frans. 'Romancing Freedom: Church and Society in the Baltic States since the End of Communism'. Religion, State and Society 27 (1999): 161-73.

Ketola, Mikko. 'The Baltic Churches in the Process of Transformation and Consolidation of Democracy since 1985'. Kirchliche Zeitgeschichte 20 (2007): Heft 1: 66-80.

- The Nationality Question in the Estonian Evangelical Lutheran Church, 1918-1939. Helsinki: Suomen kirkkohistoriallinen seura, 2000.

Kiivit, Jaan. 'Uskonnonvapaustilanne Virossa' [Freedom of religion in Estonia]. Teologinen Aikakauskirja [The Finnish Journal of Theology] 106 (2001): 550-3.

Kunter, Katharina, and Schjørring Jens Holger, eds. Die Kirchen und das Erbe des Kommunismus. Die Zeit nach 1989 - Zäsur, Vergangenheitsbewältigung und Neubeginn. Fallstudien aus Mittel- und Osteuropa und Bestandaufnahme aus der Ökumene. Erlangen: Martin-Luther-Verlag, 2007.

Lipsius, Stephan. 'Die Erneuerung kommt voran. Kirchen und Religionsgemeinschaften in Litauen'. Herder Korrespondenz 51 (1997): 99-104.

Petkunas, Darius. 'The Church in the Transition Between Socialism and Capitalism'. A copy of the manuscript in the possession of the author. [2003].

Resurgence of the Evangelical Lutheran Church in Lithuania after the Soviet Era. Macomb, MI: Lutheran Heritage Foundation, 2008.

Petti, Urmas. 'Die Estnische Evangelisch-Lutherische Kirche in einer säkularisierten Gesellschaft - ihre europäischen Perspektiven'. Lutherische Kirche in der Welt 56 (2009): $121-9$.

Plaat, Jaanus. 'Christian and Non-Christian Religiosity in Estonia in the 1990s. Comparison of Estonians and Other Ethnic Groups'. Pro Ethnologia 14 (2002): 97-134.

_. 'Eesti - luterlik või õigeusklik riik? Eestlaste ja venelaste usklikkuse võrdlus 1990$2000^{\prime}$ [Estonia - Lutheran or Orthodox? Comparing the religious properties of Estonians and Russians between 1990 and 2000]. Teologinen Aikakauskirja [The Finnish Journal of Theology] 108 (2003): 580-91.

Rozitis, Elmars E. 'Wiedergeburt und Erneuerung'. Glaube in der 2. Welt 23, no. 1 (1995): 21-4.

Stricker, Gerd. 'Bischofsnachfolge'. Glaube in der 2. Welt 23, no. 7/8 (1995): 6. $17-21$

- 'Lutheraner und Missouri'. Glaube in der 2. Welt 29, no. 10 (2001): 5-7.

'Missouri-Synode im Anmarsch'. Glaube in der 2. Welt 28, no. 12 (2000): 5-6.

. 'Umstrittene Frauenordination'. Glaube in der 2. Welt 21, no. 6 (1993): 20-4.

Walters, Philip. 'The Revolutions in Eastern Europe and the Beginnings of the Postcommunist Era'. In The Cambridge History of Christianity. Vol. 9. World Christianities c.1914-c.2000, ed. Hugh McLeod, 348-65. Cambridge: Cambridge University Press, 2005.

Zviedre, Mara. 'Life Stories of Latvian Lutheran Pastors'. Religion, State and Society 27 (1999): 175-200. 